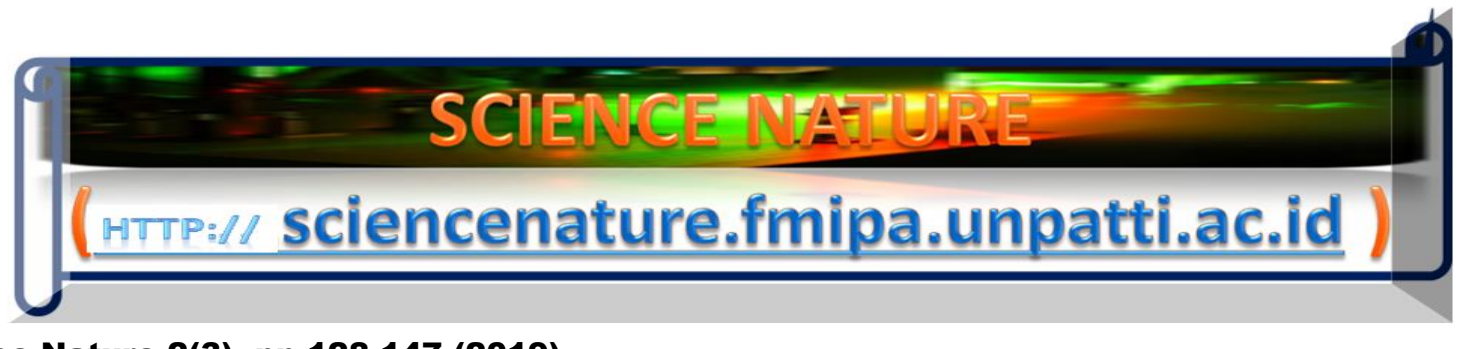

Science Nature 2(3), pp.128-147 (2019)

e-ISSN: 2654-6264

DOI: https://doi.org/10.30598/SNVol2Iss3pp128-147year2019

\title{
THE IMPLEMENTATION AND DISCOVERY OF BEST SIGNIFICANT INDICATORS OF HIGH SCHOOL QUALITY PARTICULARLY BOTH QUALITY PROCESS AND OUTPUT
}

\author{
Agnes Sukasni ${ }^{1,2 \varphi}$ \\ ${ }^{1}$ Doctoral Student, Human Resources Management, Universitas Negeri Jakarta, Indonesia \\ ${ }^{2}$ Principal of Indonesia Government High School 20 (SMA Negeri 20, Jakarta), Jakarta, Indonesia
}

Received : July 30, 2019

Revised : August 14, 2019

Published : August 22, 2019

Copyright @ All rights are reserved by Agnes Sukasni

Corresponding author: `Email: Agnessman31@gmail.com 


\section{Abstract}

The research to explain the implementation of character education programs at high school of SMAN 20 Jakarta, Indonesia, and further explained the achievements of the program. This research is a policy explanation with a descriptive qualitative approach that describes the reality of the activities studied with the aim of knowing and understanding the implementation of character education empowerment programs and evaluating the implementation of character education strengthening programs that have been, are being and will be implemented in SMAN 20 Jakarta which focuses on rules and secondary data collection. A qualitative approach is used to describe the condition as a whole about the implementation of character education. Data collection techniques are interviews, observation and documentation. The analysis technique is provided by reduction, display and conclusion, respectively. The results of this study are in the following 4 points: (1) planning starts from graduation competent standard (SKL) to socialization, (2) implementation is applied in two bases of class and school, (3) the role of school members as supervisors, coaches and implementers, and (4) supporting and inhibiting factors are the students, teachers, facilities and involvement of the school committee and parents. We obtained that there were 3 main indicators of (1). The graduation standard, (2). The process standard, and (3). Education evaluation standard which obviously improved SMA Negeri 20, Jakarta in the last 3 years through the implementation of character education especially in the last 1.5 years serious implementation.

Keywords: evaluation, policy implementation, character education

\section{ARTICLES}

\section{Introduction}

Character education has a strategic role in national development. The master plan for

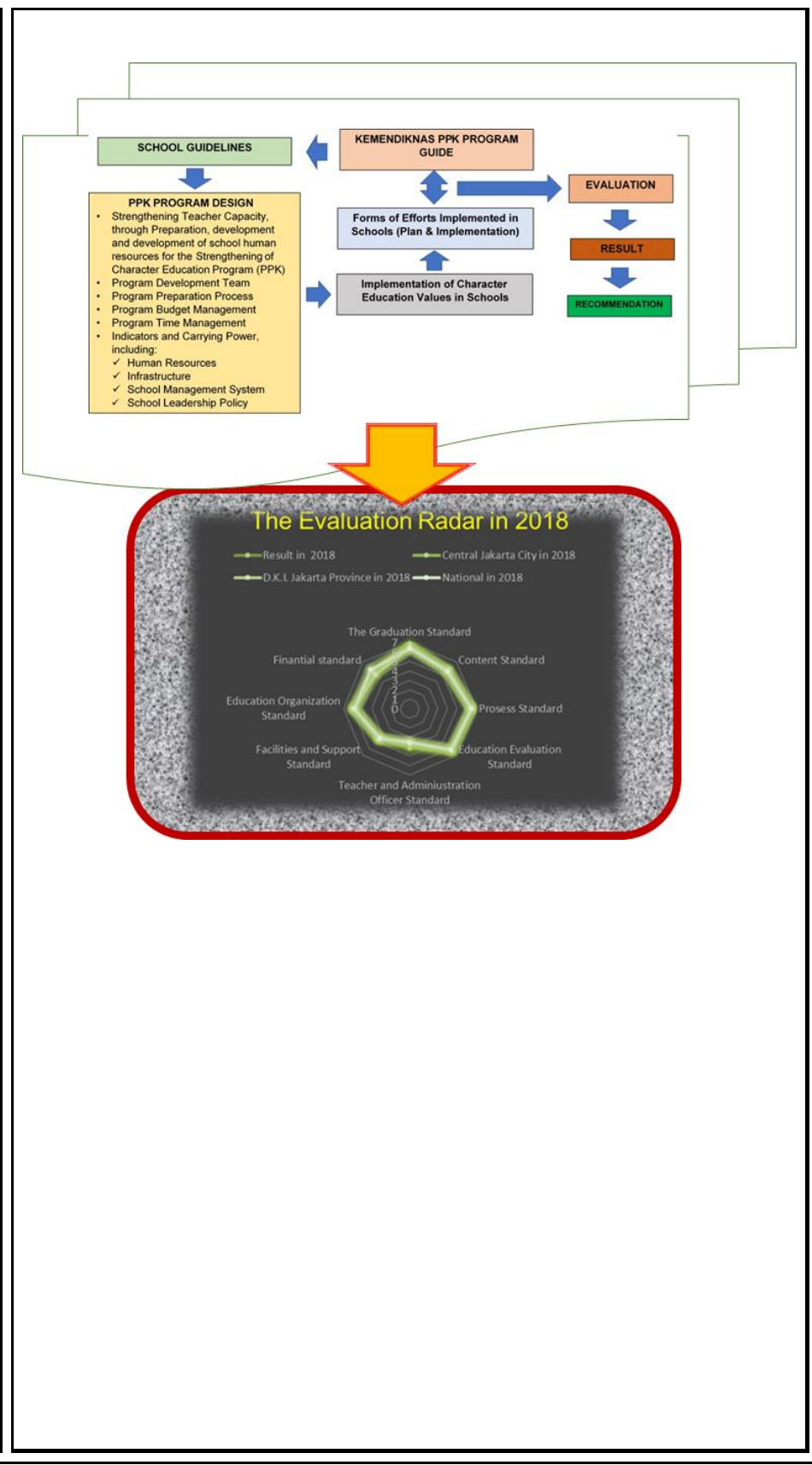

character education is needed as part of efforts to build national character. Character education regulations are regulated in Law No. 20 of 2003 concerning the National Education System (SISDIKNAS) or National Education System based on the report from Indonesia Ministry of National Education in 2003 [1]. 
The 8th point of Nawa Cita programed by President Ir. Joko Widodo is to strengthen national character education through character and student character development as part of a mental revolution. President Joko Widodo wanted to carry out the National Mental Revolution Campaign (GNRM) which would be applied in all aspects of the life of the nation and state, including in the world of education.

Character education needs to be grown and strengthened again to become a national program of national character education through the National Program for Character Building Strengthening (PPK). Educational institutions are a strategic place for the formation of national character because they have structures, systems and devices that are spread throughout Indonesia from the regions to the center of government. The formation of this nation's character is to be carried out massively and systematically through the PPK program which is integrated in the entire education system, school culture and in collaboration with the community.

The PPK program is expected to build a spirit of learning and made students happy to be in school as a friendly home to grow and develop. The aim of the character development program (KDP) program is to instill massive and effective national character-building values through the implementation of the main values of the National Mental Revolution Campaign (religious, nationalist, independent, mutual cooperation and integrity) which will be the focus of learning, habituation, and civilization, so national character education.

Education can be done in families, schools and communities [2]. The high economic demands that require parental activity and the magnitude of changes in value in society, the greater the role of schools in developing the positive character of their students. Parents strongly believe and expect that the teachers in the school can represent them to develop moral values and value systems for their children [3].

According to Koesoema in 2010, if the school is inspired by the spirit of character education it will be an effective place for the formation of individuals so that they can grow well in their environment [4]. Schools have two main objectives, namely to form intelligent and good human beings, so schools have a big responsibility in character education for their students [5]. The challenge of globalization makes character education an important part of creating quality human beings [6]. The reduced character of the nation has an impact on the Indonesian nation, so the government through the Ministry of Education and Culture (Kemendikbud) begins to reorganize the nation's generation by issuing policies to implement character education at every level of education, from kindergarten to high education [7,8]. The Ministry of Education assesses the importance of character building in the education system in Indonesia [9]. Students with strong character will improve the quality of national education. The local wisdom character is still accommodated through specific education in each region [10]. Implementation of Strengthening Character Education will be the main choice of government policy in the field of education and culture [11]. Strengthening the 5 main values of character, namely religious, nationalist, independent, mutual cooperation, and integrity in 3 core activities (intra-curricular, co-curricular, extracurricular) will be held at the PPK pilot school. 
The problem in implementing the values of character education in schools is only indoctrinative and in knowledge or theory only, and not yet at the level of implementation in daily activities. Zuhedi in Ref. [12], stated that indoctrinative moral education is only enough to stem the occurrence of behavior deviating from social norms, but it is not possible to form individuals who have independence in moral decisions. This is supported by Muslich's statement in Ref. [13], which states that character education should not only touch on the level of introduction of norms or values, but also must be at the level of internalization and concrete actions in daily life.

The research focused on evaluating the character education strengthening program implemented by SMAN 20 Jakarta in implementing character education values in accordance with the school guidelines made by the Ministry of National Education which included preparing, fostering and developing the capacity of school human resources (teachers and school staff), policies school management (principal) and student behavior in the form of student actions through daily habits.

\section{Theoretical Procedure and Research Method}

Education is expected to be able to change students in a better direction. The Ministry of National Education has formulated 18 Character Values which will be embedded in students as an effort to build national character, namely [14]: (1) Religious, (2) Honest, (3) Tolerance, (4) Discipline, (5) Hard work, (6 ) Creative, (7) Independent, (8) Democratic, (9) Curiosity, (10) Nationalism or nationalism, (11) Motherland love, (12) Appreciating achievements, (13) Communicative, (14) Love peace, (15) love to read, (16) care for the environment, (17) care for the social, and (18) responsibility.

All Values in the Character Education version of the Ministry of National Education aim to build national character through education in schools. The legal basis for implementing of character education is as follows [15]: (1) Article 31 of the 1945 Constitution, paragraph 2, second Amendment, (2) Law Number 20 of 2003 concerning the National Education System, and (3) Regulation of the Minister of National Education Number 39 of 2008 concerning Student Development. The aim of student development is: (a) Developing students' potential optimally and integrated which includes talent, interest, and creativity; (b) Strengthen the personality of students to realize the resilience of the school as an educational environment so as to avoid efforts and negative influences and conflict with the goals of education; (c) actualizing the potential of students in achieving superior achievements according to their talents and interests; and (d) Preparing students to become citizens of a noble, democratic society, respecting human rights in order to realize civil society.

The legal basis as formulated above is a law that protects the implementation of character education in schools. Character education is character education that involves aspects of knowledge, feelings, and actions. According to Thomas Lickona in Saadatul Awaliyah Pasaribu, without these three aspects education becomes ineffective [16]. According to Lickona quoted from Zubaedi in Ref. [17], correct character education must involve aspects of knowing good (moral knowing), desiring the good or loving the good (moral 
feeling), and acting the good (moral action) [17].

1. Moral knowing (moral knowledge) related to how an individual knows something abstract value that is described in 6 sub-components, including: (a) moral awareness, (b) knowing moral values, (c) perspective-taking (understanding the angle another view), (d) moral reasoning, (e) decision-making, (f) self-knowledge.

2. Moral feeling is an advanced stage in the character component described in 6 sub-components, including: (a) Conscience, (b) Self-esteem, (c) Empathy, (d) Loving the good (love kindness), (e) Self-control and (f) Humility.

3. Moral action (moral behavior) is built on 3 sub-components, among others: Competence, (b) Will and (c) Habit.

According to the Ministry of National Education, there are four principles used in the development of character education, namely: (1) Sustainability, (2) Through all subjects, development and educational unit culture, (3) Values are not taught but are built through the learning process, (4) The learning process is carried out by students actively and pleasantly. Dharma Kesuma, Cepi Triatna, \& Johar Permana quoted from Sri Narwati in 2011 [18] state that the purpose of character education are (1) Facilitating the strengthening and development of certain values so that they manifest in children's behavior, both during school processes and after the school process (after graduating from school), (2) Correcting student behavior that does not correspond to community-developed values (3) Establishing a harmonious connection with family and community in acting out the responsibility of character education together.
The function of character education is to develop abilities and form a dignified talent and civilization of the nation in educating the life of the nation. Specifically, and in detail the Ministry of Education stated that character education has the following functions [19]: (1) Formation and Potential Development, (2) Improvement and Strengthening, (3) Screening. There are five main character values derived from Pancasila, which are the priorities for the development of the national (KPP) movement; namely: (1) religious, (2) nationalism, (3) integrity, (4) independence, and (5) mutual cooperation. Each value does not stand up and develop individually but interact with each other, develop dynamically, and form personal wholeness.

This study uses a qualitative descriptive approach, with the research design used is a case study. Data collection techniques were obtained through in-depth interviews, observers as participation and documentation. The research began with collecting data owned by SMAN 20 Jakarta. The research data that has been obtained through several collection techniques was then analyzed by reducing data according to the needs of the research focus. This condition makes it easier for writers to obtain objective data in order to know and understand the implementation of character education empowerment programs and evaluation of the implementation of character education strengthening programs that have been and are being carried out in SMAN 20 Jakarta which focuses on interviews and secondary data collection. Evaluation research focuses on the Implementation of Character Education Development in SMAN 20 Jakarta. A qualitative approach is used to describe the condition as a whole about the implementation of character education. Researchers chose 
SMAN 20 Jakarta as the object of research because this school is a model school with the implementation of the Internal Quality Assurance System (SPMI) and is a school that implements School Based Management and has been appealed to be a school that applies PPK. This research was conducted by retrieving data on all elements related to the implementation of character education including aspects of Teacher (human resource, HR), Administrative Staff, Students, Parents of Students and Communities in the SMAN 20 Jakarta area. The source of information in this research is regulations and policies relating to the implementation of character education. Information obtained from the teacher is planning learning that integrates the values of character education as contained in the syllabus and lesson plans made by the teacher. Information obtained from the principal is about the implementation of character education in schools.

\section{Results and Discussion}

\subsection{Design / Planning for Strengthening the Character Education Program}

The implementation of the education system in SMAN 20 Jakarta must be in accordance with applicable management standards. The standard of education management is the national education standard relating to the planning, implementation and supervision of education activities at the level of the education, district / city, provincial, or national units in order to achieve efficiency and effectiveness in the implementation of education.

One of the management standards is education planning. According to Combs in
Nur Aedi in 2016 of Ref. [20], he is said that education planning is a rational application of systematic analysis of the process of development of education with the aim that education becomes more effective, efficient and in accordance with the needs and objectives of students or the community [21]. Didin Kurniadin \& Imam Machali said that education planning can be interpreted as a systematic process in order to prepare for future activities in the field of education. Educational planning is a process that is systematically compiled of various programs that will be implemented in the future. Educational planning aims to make the program run effectively and efficiently.

Educational planning according to Didin Kurniadin \& Imam Machali in 2013 [21] consists of: (1) goals, (2) the position of the education system, (3) alternative policies and priorities for achieving goals, (4) strategies. Besides education planning at the macro level is certainly through the stages of strategic planning to produce a plan that can be implemented as a solution that arises from various problems in the results of the analysis of internal and external education environment. At the micro level education planning can be developed with the mechanism of developing a School Development Plan (RPS) in formal education.

The education program planning component according to Enggar Dista Pratama in 2018 [22] concerning management standards includes the school's vision, mission, objectives and work plans. School Work Plan (RKS) is a planning process for all things properly and meticulously to achieve educational goals. Schools can adapt to specificities, conditions and regional potential, socio-cultural community, school potential and the needs of 
students. RKS are prepared as work guidelines in developing schools, the basis for monitoring I evaluating the implementation of school development, and as reference material to identify and submit the necessary resources. School work plans are actually another form of strategic plan. Previous terms are the school's strategic plan (Renstra), school development plan (RPS), and school program development plan.

School work plan is a comprehensive plan to optimize the use of school resources, both human resources and non-human resources to achieve desired goals in the future. School work plans should be oriented towards the future; and clearly able to address the gap between current conditions and desires, hopes or dreams to be achieved in the future.

The preparation of various school programs in SMAN 20 Jakarta must be formulated in the RKS so that the implementation is in accordance with the goals and expectations desired by the school. With this, of course in the implementation of the PPK, it must go through the same process and set out in the school work plan. According to Novan Ardi in 2012 [23], the steps in developing a character education curriculum includes: (1) Identifying and analyzing character education problems, (2) Formulating School Vision, Mission, and Objectives, (3) Formulating student behavior indicators, (4) Developing syllabus and learning plans based on character education, (5) Integrating educational curriculum content character to all subjects, (6) Developing educational assessment instruments to measure the achievement of character education programs, and (7) Building communication and collaborative schools with parents of students.
According to Barnawi \& Arifin M. in 2012 [24], the guidelines for the implementation of character education are stated that the implementation of character education is as follows: (a) Conduct an analysis of the context of the school / education unit (internal and external) conditions related to character values school education. This analysis is carried out to establish priority values and indicators of success, resources, facilities needed, and procedures for evaluating success; (b) Prepare a school action plan / education unit relating to the determination of character education values; (c) Creating a program for planning and implementing character education and incorporating the main characters that have been determined in integration through learning, integration through local content and other activities that can be integrated with the values of character education, such as self-development, professional personality development in equality education; (d) Making conditioning planning, such as: Provision of facilities, exemplary, awards and empowerment, Creation of conditions / atmosphere of the school or educational unit and Preparing teachers / educators through workshops and mentoring.

Whereas according to Sutjipto in 2011 [25] in the PPK assessment guide, it can be seen that PPK planning involves (1) Identification of the potential of early school both internally and externally, (2) PPK socialization to various parties, (3) Formulating the school's vision and mission, (4) Designing PPK policies and (5) Formulating various programs in developing PPK programs.

Planning for strengthening character education programs requires various stages that must be implemented so that the process of internalizing character values to various 
programs that have been prepared can run optimally. These stages start from the formation of a development team that is the main person in charge of implementing character education strengthening programs. The development team also has a role to identify the various potentials that exist in schools that can support various programs that will be prepared. Potential both within the school's internal scope and the school's external potential. The internal potential of the school can be in the form of potential cultural assets, school uniqueness, potential human resources, funding sources, infrastructure, existing character education programs, and school governance. The external potential of the school can be in the form of a socio-cultural environment, potential human resources around the school, moral messages or local wisdom, support from stakeholders, and potential sources of funding from outside the school [26].

The implementation of character education strengthening in SMAN 20 Jakarta is a process of socialization to all elements in the school is needed, including structural officials, teachers, school committees, parents / guardians of students, students, businesses, relevant NGOs, and other communities. They are involved in the process of formulating values that are the priority of the school so that the values applied by the school are in accordance with the local culture.

Character education is also integrated in the formulation of vision and mission and school curriculum documents such as syllabus, learning plan, and assessments. This functions so that later the goal of strengthening character education can be in line with the school's goals. In addition, there needs to be a link between the values that are the priority of the school and the main values of PPK. In designing school policies must be in accordance with character education. School policies should not conflict with the PPK implementation process. The school defines and determines the role of each party in the development of PPK, so that in its implementation each party has its own job list / job desk so that each party has a focus of work in the effort to implement the PPK program.

Schools must formulate various programs to implement the PPK program and need to pay attention to sharing factors such as the age of students, and the potential of schools. The PPK program in schools must be balanced between exercise, taste, thought, and exercise. The formulation of the PPK program can be through the process of teaching and learning activities, extracurricular activities, and school habituation activities.

Based on this description, it can be seen that the PPK implementation planning functions so that the implementation process can be measured and directed. PPK program planning also goes through school work plans where compilation starts from forming a development team; identify various potential schools; the PPK program socialization process; formulate the vision and mission of the school that integrates the PPK program; designing school policies that are in accordance with the PPK program; formulate various programs related to strengthening character education both in learning, extracurricular activities and habituation. With these various things, it is hoped that the planned program will run effectively and efficiently.

The basis for planning a character education strengthening program is government regulations on strengthening character education, observation, and data collection. The basis for character education planning can be 
elaborated as follows [26]: (1) government rules regarding strengthening character education, namely the Presidential Regulation of the Republic of Indonesia number 87 of 2017 as shown by Yetri \& Rijal Firdaos in Ref. [27] on Character Education Strengthening, (2) based on field observations, observations here are divided into three, observation based school environment conditions, observation based on human resources (teaching and education staff) and observation of student behavior results, (3) Making or processing data. The data here does not only mean character education, but also relates to students' talents of interest, so that the formulation of character education can be achieved according to objectives.

The stages of planning for strengthening the character education program consist of the first observation, in order to find out how the conditions of the school environment and also the students. Second is the coordination meeting to select a team, from all school coordinators, the core coordinator is called the school development team. The third is compiling a work program, which is assisted by the core coordinator or school development team. Fourth, namely the implementation of programs, supervision, namely the realization of work programs. The fifth is evaluation, in order to improve the quality of the program to be better than before.

\subsection{Installation of Strengthening Character Education Programs}

The PPK movement focuses on structures that already exist in the national education system. There are three structures that can be used as a way to strengthen national character education, namely: First, Program Structure, including levels and classes, school ecosystems, strengthening teacher capacity; Second, the Curriculum Structure, among others, is character building activities that are integrated in learning (intra-curricular), co-curricular, and extracurricular; Third, Activity Structure, among others, various programs and activities that are able to synergize the four dimensions of character processing from sport, thought, taste, and exercise..

The main actors in the PPK Movement are principals, educators, education personnel, school committees, and other relevant stakeholders in the development of PPK. Each party needs to understand its duties and functions in the context of the successful implementation of the PPK program. More than that, the presence of adults in the educational environment is as teachers, namely those who are guided or followed, and imitated by the students. This applies to anyone involved in educational activities.

The Strengthening of Character Education Program does not change the existing curriculum, but optimizes the curriculum in the education unit. The PPK movement needs to be carried out in educational units through various ways in accordance with the curriculum framework, namely the minimum time allocation stipulated in the Basic Framework and Curriculum Structure, and extracurricular activities managed by educational units in accordance with the interests and characteristics of students, local wisdom, carrying capacity, and policy of each education unit.

The structure of PPK activities is a choice of various kinds of activities for the formation of the character of students who balance the four dimensions of education processing according to Ki Hadjar Dewantara, 
namely olah raga, olah rasa, olah pikir and olah hati. Schools can choose the structure of activities that will encourage the formation of uniqueness, distinctiveness, and school branding. The priority choice of PPK activities is expected to encourage schools to find branding that illustrates the distinctiveness and diversity of their respective cultures. Activities that support the formation of school branding include: academic activities, non-academic activities such as sports, extracurricular activities, library utilization (arranging visiting schedules, participating in library competitions, and giving awards to students and teachers who regularly attend the library), and utilization of the potential of the environment, such as art studios and museums.

In the installation stage, the learning experience and learning process stages are developed which lead to the formation of character in students. This process is carried out through a process of empowerment and civilization as outlined as one of the principles of the implementation of national education. In this process there are two types of learning experiences that are built through two approaches, namely intervention and habituation. In the intervention developed an atmosphere of learning and learning interactions that are intentionally designed to achieve the goal of character building by implementing structured activities. For the learning process to be effective, the role of the teacher as a role model is very important and decisive.

Meanwhile in habituation situations and conditions are created and reinforcement that makes students at home and the community environment can behave according to values and become characters who have been internalized and personalized through the intervention process. The process of civilization and empowerment is done by giving examples, learning, habituation, and reinforcement must be developed systemically, holistically, and dynamically.

In terms of character education assessment, there are no instruments that can be used appropriately. The teacher is still having difficulties in compiling character education assessment instruments so that it is necessary to develop character education assessment instruments in learning in schools according to the characteristics of students. The development of an instrument for assessing character education in the learning process in schools will facilitate teachers in carrying out assessments of the character education process so that the implementation of character education for students can take place to support the realization of national education goals.

The final results expected from this development are obtained: Integrated character education assessment instrument in Social Humanities subjects in schools, which consists of character education assessment tests for students, character education questionnaires through by teachers, and character education assessment questionnaires through by parents. The development of an integrated character education assessment instrument in school learning is carried out following the steps in developing a learning program. These steps include: (1) Development of syllabus, (2) Preparation of learning implementation plans (RPP), and (3) Implementation of Learning. Monitoring and evaluation of draft integrated character education assessment instruments in school subjects is carried out by conducting observations on the implementation of integrated character education in learning, conducting interviews with classroom teachers 
and students. The PPK Program design framework is shown in Figure 1. The stages of the installation include the reassessment of established designations, monitoring the programs being carried out and examining the gaps that occur between the program guidelines that have been planned and what has been achieved.

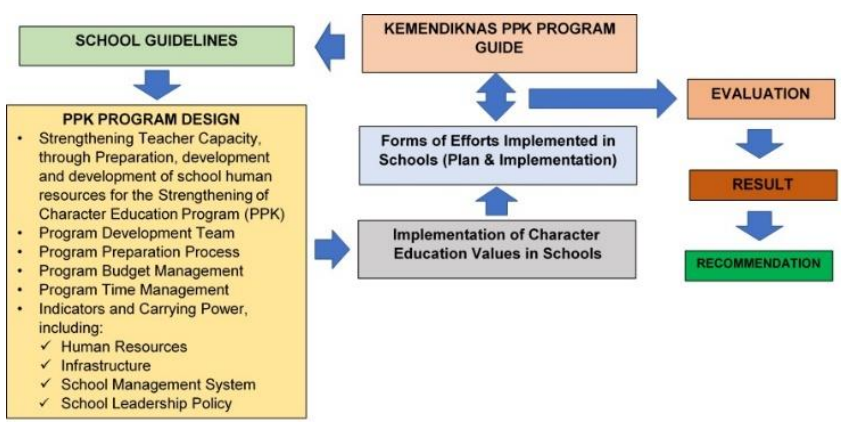

Figure 1. Installation of the PPK Program Flow Frame.

An educational institution like SMAN 20 Jakarta needs an organization for a good coordination process. This condition can facilitate the school in carrying out the planning that has been made. The principal is responsible for activities, assisted by the school development team and coordinators. The coordinator is student coordinator, coordinator of facilities and infrastructure, coordinator of school relations with the community, and others. As for the implementation of the management of character education reinforcement programs are as follows: (1) the principal, as the responsible for activities, and school policies, (2) the school development team, which consists of curriculum coordinators and school quality developers, namely assisting headmaster in monitoring, making work programs, and helping with the activities program, (3) school coordinators, helping the school development team.

\subsection{Process / Implementation of Character Education Strengthening Program}

After the education program planning process is followed by the implementation or implementation process. In the implementation of educational programs tailored to the plans that have been prepared so that later the objectives of the program can be achieved properly. In accordance with Permendiknas No. 19 of 2007 [28], the process of implementing school programs must be based on school guidelines. According to Ref. [28], schools make and have guidelines that regulate various aspects of management in writing that are easily read by the parties concerned. The formulation of school guidelines must pay attention to: (1) considering the vision, mission and objectives of the school / madrasah; (2) periodically reviewed and reformulated in accordance with community development. This school guide serves as an operational implementation guide.

The implementation of the education program must be in accordance with the education program plan. The implementation of educational programs according to school guidelines that have been prepared based on the program plan include: program objectives, time, place and so on. The implementation of the PPK program must be in accordance with the school work plan and based on the school guidelines that have been made so that the implementation will be directed according to the objectives. Organizing character education in schools can be carried out in an integrated manner at each school activity. Every activity of students in schools can be used as a medium to instill character, and facilitate students to behave according to character values. In the implementation of PPK, it can be done through 
three main channels, namely 1) formal education, 2) non-formal education, 3) informal education.

PPK can be implemented integratively and collaboratively, as explained by Yetri \& Rijal Firdaos as follows [26]: (1) Integrative is learning that integrates character development with the substance of the subject contextually. Contextual are intended starting from learning planning to assessment and (2) Collaborative is learning that collaborates and empowers various potentials as a source of learning and / or community involvement that supports Strengthening Character Education.

According to Ref. [26] in the implementation of PPK can be implemented with existing curriculum-based namely: (1) Strengthening Class Based Character Education, namely integrating the learning process in the classroom through curriculum content in thematic subjects as well as integrated subjects, strengthening classroom management, choice of methodology, evaluating teaching, and developing local content according to regional needs; (2) Strengthening Character Education Based on School Culture, namely emphasizing the habituation of the main values in the school's daily life, showing the example of adults in the education environment, involving the entire ecosystem of education in schools, developing and giving a wide range of potential students through curricular activities and extra-curricular activities, empowering school management and governance, and considering school norms, rules and traditions; (3) Strengthening Character Education based on community, namely strengthening the role of School Committees and parents as the main stakeholders of education, involving and empowering the potential of the environment as a source of learning such as the existence and support of arts and cultural activists, community leaders, businesses and industry, synergizing PPK implementation with various programs in academia, education activists, and NGOs and synchronizing programs and activities through collaboration with local governments, government ministries and agencies, and the public in general.

The implementation of PPK certainly requires a variety of strategies that can facilitate the process of internalizing character values to students. Based on Yetri \& Rijal Firdaos [26], the strategy for implementing PPK in education units can be carried out through the following activities [27,28]: (1) Intra-curricular activities, (2) Cocurricular activities, (3) Extracurricular activities, (4) Integrating subjects that are in the structure of the curriculum and subjects of local content (Mulok) through intra-curricular and co-curricular activities, (5) Implementing PPK through extracurricular activities determined by the education unit, and (6) Habitual activities through school culture are formed in the process of routine, spontaneous, conditioning, and exemplary activities of school people.

The implementation of the PPK program according to the Ministry of Education and Culture has several ways, the first is through teaching and learning activities, namely integration in subjects and local content. The development of the values of cultural education and national character are integrated into each subject of each subject. These values are included in the syllabus and lesson plan. Learning activities within the framework of character development learners can use active learning approaches such as contextual learning approaches, cooperative learning, problem-based learning, project-based learning, service learning, work-based learning, 
and ICARE (Introduction, Connection, Application, Reflection, Extension) can used for character education [28]. While local content is developed or determined through education / regional units [29].

The second way is through non-KBM activities such as extracurricular activities. Planting character values can be done through various extracurricular activities such as Pramuka, PMR, sports activities etc. These activities are expected to be able to support the planting of character values to students. In addition, the third way can be through habituation through school culture, for example as depicted in Ref. [30]: (1) Implementing exemplary, (2) Routine Activities Routine activities are activities carried out by students continuously and consistently at all times, (3) Spontaneous Activities and (4) Conditioning which is the creation of conditions that support the implementation of character education.

Based on this description, it can be concluded that the implementation of strengthening character education can be done by integrating in the process of learning, extracurricular and habituation, or more commonly called school culture. In the implementation of strengthening character education it is not only the obligation of the school but the community (non-formal) and family (informal) means that the school can collaborate so that the implementation of PPK can run effectively and get appropriate results. The implementation of the PPK program is based on the school guidelines that have been made so that the implementation can be directed according to the goals and expectations.

The Ministry of National Education develops the grand design of character education for each path, level, and type of education unit. This activity was carried out to improve the suitability and quality of character education. The mindset of national character development according to the Ministry of National Education can be seen in Figure 2. Based on the grand design, education is one of the basic strategies of national character development which is carried out in several strategies. The character education strategy can be applied through socialization, education, empowerment, civilization and cooperation. Psychologically and culturally the formation of character in an individual is a function of all potential individuals, both in cognitive, affective and psychomotor aspects in the context of cultural social interactions: in families, schools, and communities that last throughout life.

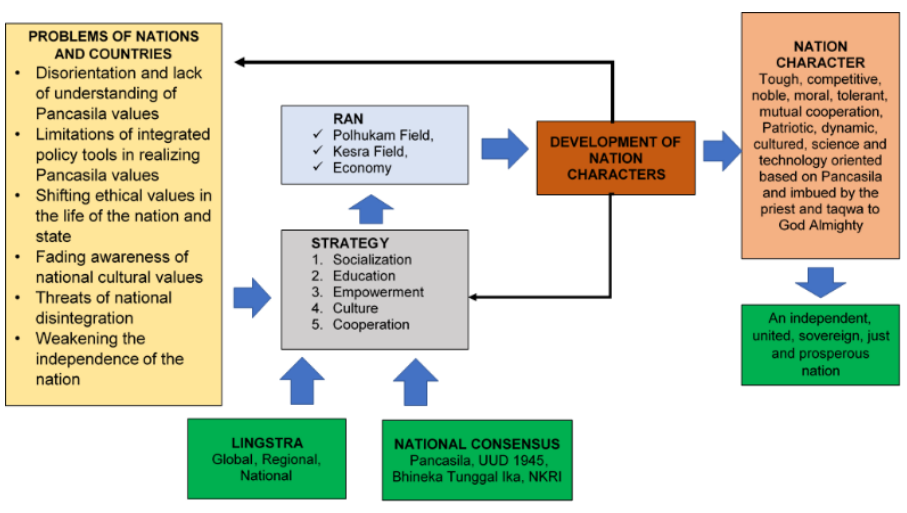

Figure 2. Flow Chart of National Character Development [27].

The implementation of character education values in schools can run well, so things must be done: (1) examples from teachers, principals, and school management; (2) character education is carried out consistently and continuously; and (3) planting the main character values. The values of character education must also be applied through daily life habits in school through school culture. 
The implementation of strengthening the character education program is a realization of the previously determined plan. The activities for strengthening character education programs in schools are: (1) integration, in order to adapt to previous school programs, (2) civilization, can be interpreted as habituation activities which contain five main values of strengthening character education, including religious, nationalism, mutual cooperation, independence, and integrity, (3) exemplary, students are expected to be able to imitate the good things that have been taught or exemplified by teachers in schools, (4) cooperation with parents of students, to take part in school programs and provide support for the work the character education strengthening program. The implementation of the PPK program in schools can be seen in Fig. 3 .

The implementation of the main character values as an embodiment of 18 other character values is a great capital to improve the character of students. Through the movement to strengthen character education, it is expected that students can realize the golden generation of 2045 with the character in accordance with the Indonesian Nation's identity, namely Pancasila.

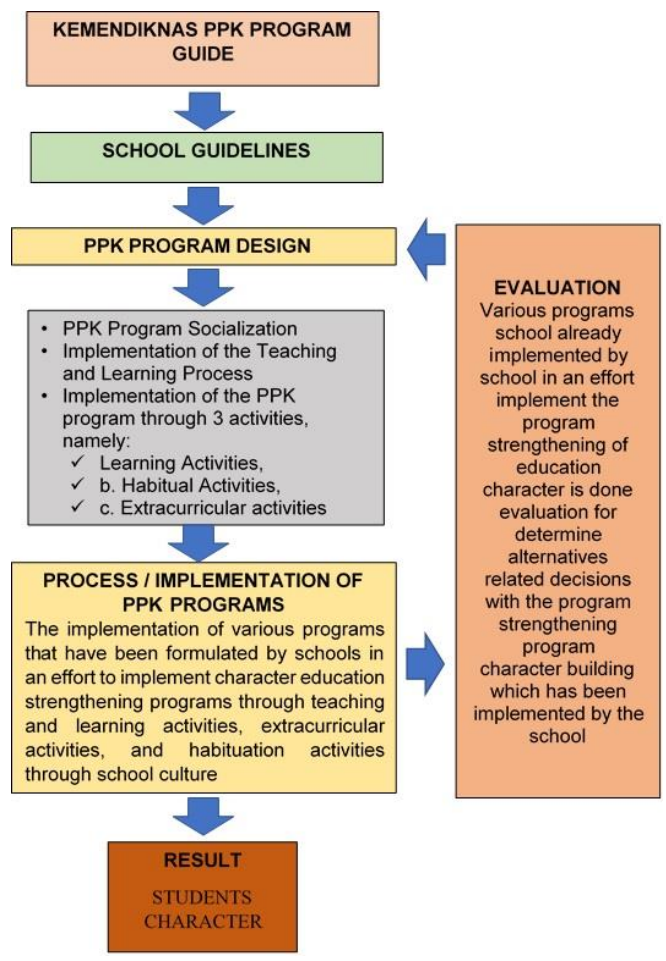

Figure 3. Implementation of the PPK Program in Schools.

\subsubsection{Evaluation of Strengthening the Character Education Program}

The implementation of various programs wants to get results as expected. Evaluation is an activity to collect information about the workings of something which is then used to determine the right alternative in making a decision [31]. In addition, according to Stuffebleam in Nur Aedi of 2016 [20] suggests educational evaluation, namely "Focutional evaluation is the proses of delineating, obtaining and providing useful information for judging decision alternative". Educational evaluation is a process of describing, collecting and presenting information useful for setting alternative decisions.

Based on the meaning of educational evaluation it is known that evaluation of educational programs is a process of collecting 
and presenting information about a program or activity that has been running in order to determine alternative decisions. Alternative decisions are in accordance with the interests of the evaluator whether the program can be continued or not and so forth. The results of this evaluation are useful for self-reflection, sorting out various programs that have high or low results according to the achievement indicators that have been prepared previously. According to Ref. [21], there are 3 important points: (1) obtain the basis for a period of work, what has been achieved, what has not been achieved, and what needs special attention, (2) guarantee effective and efficient work methods that bring educational organizations (human / labor, facilities / infrastructure, costs) efficiently and economically, and (3) obtain facts about difficulties, obstacles, and deviations seen from certain aspects such as the annual program and learning progress. According to document shown in Ref. [31] in broad outline the program evaluation is divided into several stages, namely [30]: (1) Program evaluation preparation, (2) Program evaluation, and (3) Monitoring the implementation of the evaluation program.

The evaluation of educational programs must be carried out by an evaluation process to see the success of the program in achieving the expected results. This is included in the implementation of the character education strengthening program. The evaluation was carried out based on a scheme that had been approved by the PPK team of the Ministry of Education and Culture. According to Yetri \& Rijal Firdaos in Ref. [26], it was stated that the objective of the PPK program evaluation was (a) Obtain data and information needed to determine the effectiveness of strengthening of the Character Education Program; (b) Obtain an overview of the achievements of the goal of Strengthening of Character Education; (c)
Obtain information about the difficulties and obstacles during the implementation of Strengthening of the Character Education Program; (d) Assessing the success of the implementation of Strengthening of the Character Education Program; (e) Determine constraints and obstacles in the implementation of Strengthening of the Character Education Program; and (f) Identify the sustainability of Strengthening the Character Education program [26].

The PPK program evaluation is carried out through observation, document analysis, surveys, interviews and data discussions to collect data, both administrative data and supporting records to assess a program or activity. According to Enggar Dista Pratama in Ref. [22] the process of evaluating character education is through the following stages: Assessing success and supervision. For the continuity of the implementation of character education it is necessary to evaluate success by using indicators in the form of behavior of all citizens and the condition of the school / educational unit observed. This assessment is carried out continuously through various strategies [27]. Supervision is carried out starting from reviewing the planning, curriculum, and implementation of all activities related to character education, namely: (a) Implementation of self-development programs related to the development of values of cultural education and national character in the culture of schools / educational units; (b) Completeness of supporting facilities and infrastructure for the implementation of the development of the value of cultural education and national character; (c) Implementation of character education values in learning; (d) Implementation of active learning in learning activities; (e) Achievement of School Action 
Plans / educational units relating to the application of character education values; (f) Assessment of the application of the value of character education to educators, education staff and students (as final conditions); and (g) Comparing the initial conditions with the final conditions and designing a follow-up program.

In the evaluation process, the school formed an evaluation team tasked with carrying out the PPK program evaluation process. The evaluation team must have instruments to measure and document the success of the PPK program. The process of evaluating the PPK program, schools also need to pay attention to several things such as: using supporting data for school attendance, diaries, etc.), involving all available human resources in the implementation of PPK programs, and utilizing various media, facilities and infrastructure. or various school potentials that exist in assessing the success of the PPK program. These things can be included in the data collection process to support the evaluation results. This is needed to see clearly the conditions / results of various PPK programs that have been implemented.

Processing and conclusions are carried out after the data collection process. The data obtained was then followed up by the school to improve the implementation of the PPK program. In addition, a feedback mechanism is also needed so that what students feel can be taken into consideration by the school in determining future PPK programs. From the various descriptions above, the PPK program evaluation is needed to collect and describe data in the PPK program implementation, which later results from the evaluation are used to determine further decisions regarding the PPK program. In the evaluation process there are several stages, namely: the formation of an evaluation team, formulating a success assessment instrument, conducting data retrieval based on existing instruments, conducting a description process, analysis, and discussing the data obtained, conclusion of results, and follow up or follow-up by the school. PPK program evaluation is useful for sorting out various PPK programs that are already running which have high or low success rates so that these results can be used as a reflection material for PPK program planning, which in turn can be more effective and efficient.

\subsubsection{Benefit of the Results of the Implementation of the Character Education Program}

Six (6) Benefits of the Character Education Program, namely [27-28]: (1) Strengthening the character of students in preparing the competitiveness of students with 21st century competencies, namely: critical thinking, creativity, communication, and collaboration; (2) Learning is carried out integrated in schools and outside schools with teacher supervision; (3) Revitalizing the role of the Principal as manager and Teacher as PPK inspirator; (4) Revitalization of School Committees as institutions for school collaboration and community participation; (5) Strengthening the role of the family through a 5 (five) day learning policy; and (6) Collaboration between family / environment, local government, community institutions, education activists and other learning resources.

Strengthening aspects in the Character Education program in SMAN 20 Jakarta include: (1) Revitalizing school-based management through Broad Based Education (BBE); (2) Intra-curricular, co-curricular, 
extra-curricular, and non-curricular synchronization, and integrated schools with the activities of the arts, culture and language, sports, science, and religious arts communities; (3) Deregulation of strengthening the capacity and obligations of the Principal / Teacher; (4) Preparation of infrastructure / learning facilities (for example: procurement of books, consumption, art equipment, teaching aids, etc.) through the establishment of collaborative networks for public involvement; (5) Gradual implementation by considering the condition of infrastructure and regional / regional cultural diversity; and (6) Organizing and transparent and accountable systems for controlling public engagement.

Character education at SMAN 20 Jakarta which is implemented in self-development education, among others; through extracurricular activities in schools, for example: student council administrators, Pramuka, PMR, PKS, KIR, sports, arts, religion and others. The extracurricular activities this is very touching, easy to understand, and carried out by students as part of channeling the interests and actions of students as part of channeling interests and talents that can be developed as an embodiment of national character education.

Finally, after about 3 years deep studies in the interval time of 2016 to 2018, the improvement quality in SMA Negeri 20, Jakarta has been significantly observed as depicted in Fig. 4. One obtained that there were at least 5 important indicators from the total 8 measurement indicators for a very competent high school in the whole country of Indonesia such as (1). The graduation standard, (2). The process standard, (3). Education evaluation standard, (4). Education organization standard, and (5). Financial standard. Among these 5 main factors, one finds out that there were 3 obvious indicators which mainly contributed to significantly improve the whole education system in SMA Negeri 20, Jakarta as follows: (1). The graduation standard, (2). The process standard, and (3). Education evaluation standard. The results were then compared to the whole Central Jakarta, the whole Jakarta and the whole Indonesia nation (National) as shown in Fig. 4.

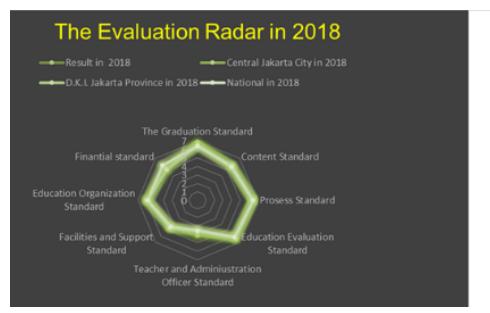

A Comparison of the Evaluation Radar from 2016 to 2018

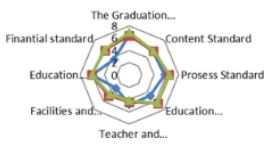

Figure 4. The evaluation radar closely associated with the whole education achievement and it's all standard indicators of SMA Negeri 20, Jakarta in comparison with that of Central Jakarta high schools, and the whole Jakarta high schools as well as the whole Indonesia high schools, respectively.

\section{Conclusion}

Character education has a strategic role in national development and a character education master plan is needed, as part of efforts to build national character. Character education needs to be developed and strengthened again to become a national character education program through Strengthening the PPK. The challenge of globalization makes character education an important part of creating quality human beings. The reduced character of the nation has an impact on the Indonesian nation, so the government through Kemendikbud has begun to reorganize the nation's generation by issuing policies on character education at every level of education, from kindergarten to higher 
education. PPK program planning at SMAN 20 Jakarta is carried out through school work plans where the preparation starts from forming a development team; identify various potential schools; the PPK program socialization process; formulate the vision and mission of the school that integrates the PPK program; designing school policies that are in accordance with the PPK program; formulate various programs related to strengthening character education both in learning, extracurricular activities as well as school habituation / culture. Benefits of the Character Education Program for SMAN 20, Jakarta, namely: strengthening the character of students in preparing students' competitiveness; learning is carried out integrated with teacher supervision; revitalizing the role of Principal as manager and Teacher as PPK inspiratory shepherd, revitalization of School Committees as institutions for school collaboration and community participation; strengthening the role of the family through learning policies; and collaboration between K/ L (family / environment), local government, community institutions, education activists and other learning resources. In addition, it has been discovered that there are 3 main indicators of (1). The graduation standard, (2). The process standard, and (3). Education evaluation standard which have been clearly improved through character education in SMA Negeri 20, Jakarta in the last 3 years. Therefore, one suggests that may these research findings be a short cut knowledge to improve another high school's education system as well.

\section{Aknowledgement}

The author would like to thank SMA Negeri 20, Jakarta for both motivation and financial support. A.S is grateful to Assoc. Prof. H.I.
Elim for suggestions and encouraged discussion in improving this paper.

\section{References}

[1]. Ichsan Anshory, Dyah Worowirastri Ekowati, \& Erna Yayuk, Ethno-Education: Pendidikan Dalam Perspektif Budaya Dalam Rangka Penguatan Pendidikan Karakter Para Calon Guru Di Pgsd Fkip Umm, Seminar Nasional Kedua Pendidikan Berkemajuan dan Menggembirakan. ISBN: 978-602-361-102-7. Hal 533-543 (2017).

[2]. Nasiruddin, Peran Keluarga, Sekolah, Dan Masyarakat Dalam Pendidikan Karakter Generasi Muda Bangsa, Prosiding Seminar Nasional Tahunan Fakultas Ilmu Sosial Universitas Negeri Medan Tahun 2017 Vol. 1 No. 1, Hal. 339-343 (2017).

[3]. N.A.R. Ghamrawi, N. Ghamrawi, and T. Shal, Perception of Character Education: The Case of Lebanese School Leaders. Open Journal of Leadership, 4, pp. 129-142 (2015). http://dx.doi.org/10.4236/oj1.2015.44012

[4]. Doni Koesoema, Pendidikan karakter. Strategi Mendidik anak di Jaman Global.Edisi ke 2, Jakarta: Grasindo, Hal. 79-80 (2010).

[5]. Hadi Wiyono, Pendidikan Karakter dalam Bingkai Pembelajaran di Sekolah, Jurnal Ilmiah CIVIS, Volume II, No 2, Hal. 132-142 (2012).

[6]. Triatmanto, Tantangan Implentasi Pendidikan Karakter di Sekolah, Jurnal Cakrawala Pendidikan Th. XXIX. Edisi Khusus Dies Natalis UNY, Hal.187 (2010).

[7]. Jarot Tri BowoSantoso, Karakter Dan Pemahaman Pendidikan Karakter Mahasiswa Pendidikan Akuntansi Melalui Pembelajaran Strategi Belajar Mengajar Berkarakter, Jurnal Pendidikan Ekonomi Dinamika Pendidikan, Vol. Viii, No. 1, Hal. 11 - 25 (2013).

[8]. Aynur Pala, The Need for Character Education, International Journal of Social Sciences and Humanity Studies, Vol 3, No 2, Issn: 1309-8063, Hal. 23-32 (2011).

[9]. Kompas, Pentingnya Pendidikan Karakter Bangsa, Edukasi, kompas.com. dated on 20 April (2010).

[10]. L. R. Retno Susanti, Membangun Pendidikan Karakter Di Sekolah: Melalui Kearifan Lokal, Disampaikan Pada Persidangan Dwi tahunan FSUA-PPIK USM Pada Tanggal 26 S/D 27 Oktober 2011 Di Fakultas Sastra Unand, Padang (2011). 
[11].http://www.tribunnews.com/nasional/2016/12/30/ta hun-2017-mendikbud-genjot-penguatan-pendidikan-k arakter. Jumat, 30 Desember 2016. Uploaded on 7 Desember (2017).

[12]. Darmiyati Zuchdi, Panduan Implementasi Pendidikan Karakter Terintegrasi dalam Pembelajaran dan Pengembangan Kultur Sekolah. Yogyakarta: UNY Press. Hal. 5, (2012).

[13]. Masnur Muslich, Pendidikan Karakter Menjawab Tantangan Krisis Multidimensional, Jakarta: SinarGrafika Offset. Hal. 85 (2011).

[14]. H.R. Mansur, Implementasi Pendidikan Karakter Di Satuan Pendidikan, Artikel LPMP Sulselin Desember ISSN. 2355-3189. Hal. 6 (2014).

[15].Fakhrizal. http://www.jejakpendidikan.com/2017/01/landasanpendidikan-karakter.html. $30 \quad$ January 2017. Downloaded on 7 Desember (2017).

[16]. Saadatul Awaliyah Pasaribu, Konseptualisasi Pendidikan Anak Usia Dini Berbasis Pendidikan Karakter, Prosiding Seminar Nasional Tahunan Fakultas Isipol Universitas Negeri Medan Tahun Vol. 1 Hal. 403-406 (2017).

[17]. Zubaedi, Pendidikan Berbasis Masyarakat (Upaya Menawarkan Solusi Terhadap Berbagai Problem sosial), Yogyakarta: PUSTAKA PELAJAR. Hal. 7-8 (2005).

[18]. Sri Narwanti, Pendidikan Karakter (Pengintegrasian 18 Nilai Pembentuk Karakter Dalam Mata Pelajaran). Yogyakarta: Familia, Hal. 17 (2011).

[19]. Zulhijrah, Implementasi Pendidikan Karakter Di Sekolah, Jurnal Tadrib Universitas Raden Fatah, Vol. 1 No.1, hal. 2 - 19 (2015).

[20]. Nur Aedi, Dasar-Dasar Manajemen Pendidikan, Yogyakarta: Gosyen Publishing, hal. 178, 182, 205 (2016).

[21]. Didin Kurniadin dan Imam Machali, Manajemen Pendidikan Konsep dan Prinsip Pengelolaan Pendidikan, Yogyakarta: Ar-Ruzz Media, hal. 141, 376 (2013).

[22]. Enggar Dista Pratama, Pelaksanaan Penguatan Pendidikan Karakter (PPK) DI SMK Negeri 2 Pengasih, Skripsi Fakultas Teknik Universitas Negeri Yogyakarta, 2018.

[23]. Novan Ardi W., Manajemen Pendidikan Karakter: Konsep Dan Implementasinya Di Sekolah (Yogyakarta: Pedagogia, h. 94 (2012).

[24]. Barnawi dan Arifin M. Strategi \& Kebijakan Pembelajaran Pendidikan Karakter. Jogjakarta: Ar-ruz Media (2012).

[25]. Sutjipto, Rintisan Pengembangan Pendidikan Karakter di Satuan Pendidikan, Jurnal Pendidikan dan Kebudayaan, Vol. 17, Nomor 5, Hal. 501-524, September 2011.

[26]. Yetri \& Rijal Firdaos, Penguatan Pendidikan Karakter Berbasis Masyarakat Pada Sekolah Menengah Pertama Negeri (SMPN) Di Kabupaten Tulang Bawang Provinsi Lampung, Al-Tadzkiyyah: Jurnal Pendidikan Islam, Volume 8, No. II (2017).

[27]. Ibid, Enggar Dista Pratama hal.29.

[28]. Kemendikbud, Permedikbud No 20 Tahun 2016: “Tentang Standar Kompetensi Lulusan Pendidikan Dasar dan Menengah", published in Jakarta at Kemendikbud, (2011).

[29]. Suharsimi Arikunto dan Cepi Safruddin, Evaluasi Program Pendidikan Edisi Kedua, Jakarta, PT Bumi Aksara publioshing, p. 2, 108 (2013).

[30]. Sofyan B., Eksistensi Muatan Lokal dalam Kurikulum Lembaga Pendidikan Agama dan Pendidikan Keagamaan di Sulawesi Barat, Inovasi Kurikulum Berbasis Lokal di Pondok Pesantren. Jakarta: Balai Penelitian dan Pengembangan Agama. (2008).

[31]. http://www.websitependidikan.com/2017/01/ pengertian-konsep-dasar-dan-manfaat-penguatan-pe ndidikan-karakter-serta-hal penting-terkait-ppk.html 


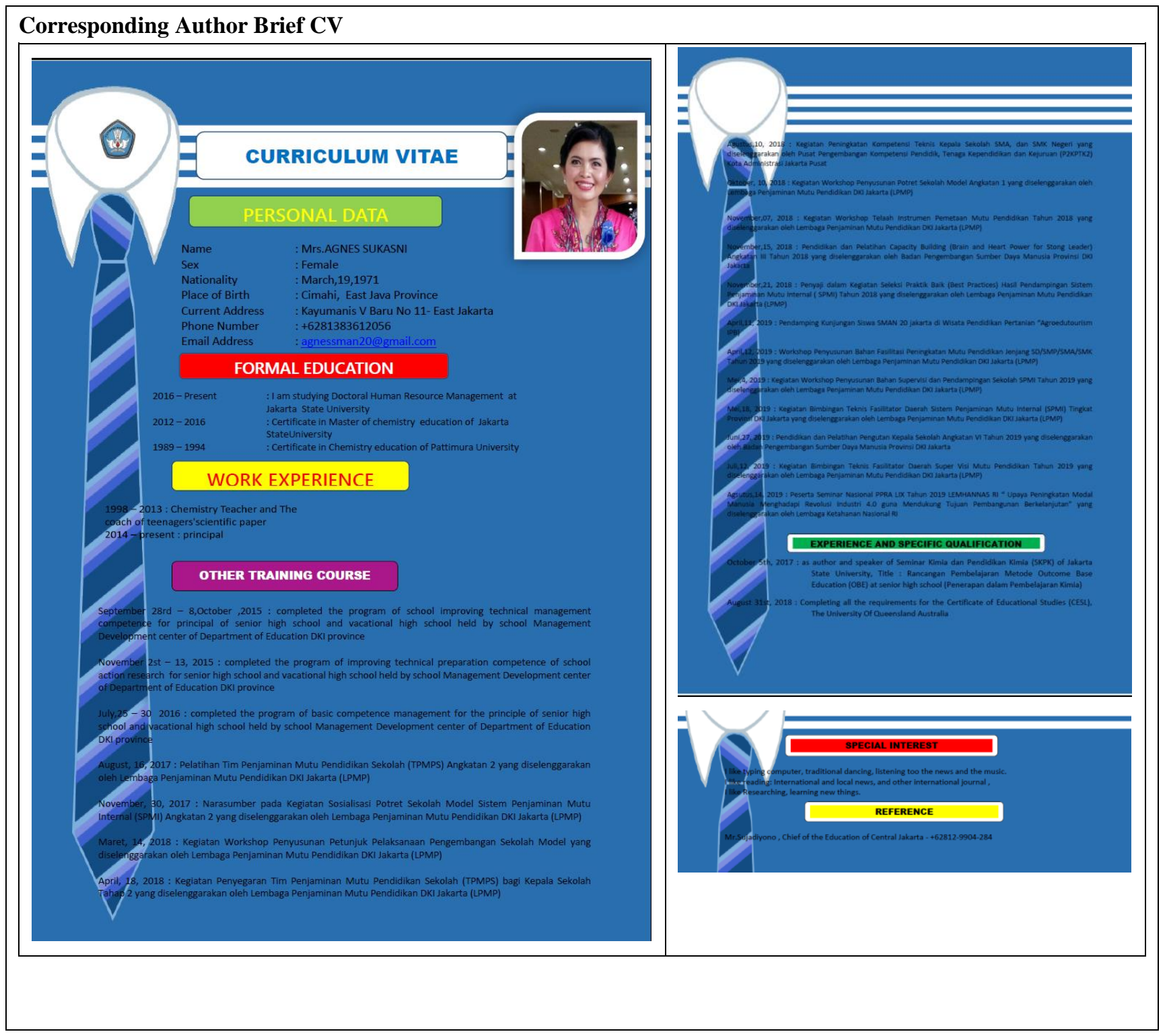

E-ISSN: 2654-6264

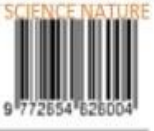

